\title{
Role Duality among School-age Children Participating in Farming in Some Villages in Kwara State, Nigeria
}

\author{
Rashid S. Adisa* \\ \& Oluwasegun A. Adekunle**
}

\begin{abstract}
The paper examines rural children's role duality as school pupils and farm participants. Multi-stage cluster random sampling was used to elicit data from 229 respondents aged between five and sixteen years. It was found that 44 per cent of the respondents were simultaneously schooling and farming, while the remaining were only either in school or farming. Using eight common farm activities, a coefficient of farm participation (cfp) was computed, while another eight agricultural innovations were used to compute agricultural innovation awareness index (awi) for each respondent. It was found that no significant difference existed in farm participation levels of respondents attending school and those that were not, while a significant difference in innovation awareness (awi) existed in favour of respondents in school. Parental influence, peer group and school farms were also found to be significantly related to respondents' participation in agriculture. It is thus imperative to keep rural children in school even as they are engaged in farming activities.
\end{abstract}

\section{Résumé}

Cet article examine la dualité du rôle des enfants vivant en milieu rural en tant qu'écoliers et en tant qu'intervenants dans les activités agricoles. Un échantillonnage aléatoire en plusieurs étapes a été pratiqué pour tirer au clair les

* Corresponding Author, Department of Agricultural Extension and Rural Development, University of Ilorin, PMB 1515, Ilorin, Nigeria. E-mail: rsadisa@yahoo.com

** Department of Agricultural Extension and Rural Development, University of Ilorin, P.M.B. 1515, Ilorin, Nigeria. E-mail: setokade@yahoo.com 
données provenant de 229 enfants de cinq à seize ans interrogés. Il en est ressorti que 44 pour cent des sujets interrogés étaient à la fois écoliers et ouvriers agricoles, tandis que le pourcentage restant est soit à l'école soit aux champs. A l'aide de huit activités agricoles courantes, un coefficient de participation aux travaux agricoles (сра) a été calculé, tandis que huit autres innovations agricoles ont été utilisées pour calculer l'indice de prise de conscience des innovations agricoles (isia) de chacun des enfants interrogés. Aucune différence fondamentale n’a été découverte quant aux niveaux de participation aux travaux agricoles entre les enfants scolarisés interrogés et ceux qui ne l'étaient pas. Il y a une différence notable de prise de conscience des innovations de la part des enfants interrogés qui sont scolarisés. Il a ainsi été découvert que l’influence parentale, celles des pairs et des fermes-écoles pèsent sur la participation des enfants interrogés aux travaux agricoles. Il est donc impératif de maintenir à l'école les enfants vivant en milieu rural même lorsqu’ils sont préposés à des activités agricoles.

\section{Introduction}

Agricultural production has remained a crucially important aspect of humanity's existence on earth in several ways. Arguably beginning with fruits and wild plants gathering to meet early humans' basic needs, agricultural production has transcended all reasonable bounds in exerting a remarkable influence on the lives of the world's inhabitants. It is however not its primordiality that epitomises its relevance. Its universality, development and potentials to meet the challenges of ever-increasing human population insure its immortal significance.

It is perhaps the appreciation of this fact that has made agriculture the dominant occupation in many nations. Especially in developing countries, family units have been, and still are, the major source of farm labour. Family members, including children, are involved one way or the other in agricultural production. That children are becoming increasingly noticeable in farming may not be astonishing because, in many rural areas, farming has become a culture which parents pass on to their offspring, who in turn do same to theirs and so on. And whether for socialisation or economic reasons - as found in developing countries - or for learning and amusement as in developed nations, children's involvement in farming is a reality and, perhaps, a necessity (Olutayo 1994; Ginsberg 2000). This is particularly true of developing countries like Nigeria where mechanised agriculture has remained largely elusive at the same time as the farming population and the younger generations’ interest in farming are declining (FOS 1996; Ngwu 1993).

School-age children's participation in farming however carries great implications now and in the future. For instance, most farming families in 
Nigeria begin to introduce their wards to farm-work as early as the age of five. This, incidentally, is the age that they should begin school. There is therefore a compelling need to reconcile the desire of parents to sensitise children to be interested and participate in farming with that of fulfilling their children's rights to a good education. This is bearing in mind that sustainable development entails meeting our present needs in a way that does not jeopardise future generations' ability to meet their own (Waldie 2004). How then do we achieve this balance? It is conventional, and perhaps inevitable, to describe childhood based on an age criterion. For instance, in Nigerian law, a child is any person below the age of 15 years (Etim 1989). The definition of childhood, however, may vary from place to place and time to time, as there are varying thresholds for delineating childhood and adulthood. In some societies, the 'fulfillment of certain social rites are prerequisite while in others, the integration of children to socio-economic life begins so early that it may be difficult to clearly identify different life phases' (Bequile 1983: 17). While defining child labour, Blanchard (1983) excluded children working on family farms and those working a few hours for pocket money or excitement. Farming has become such an entrenched way of life in many societies that 'it is hardly meaningful to regard working in family farms by children as child labour' (Kissekka 1989: 6). These submissions are however controversial and contrary to the views of many other researchers such as Olawale and Solola (1999) who considered children's work in family farms as child labour. It is however clear that working in farms may lead to the duality of their roles, since they must also attend school.

The specific objectives of this paper are to:

(i) Identify the factors influencing children's participation in farming activities in the study area;

(ii) Investigate role duality among respondents vis-à-vis their participation in family farms and agricultural innovation awareness;

(iii) Develop an education-friendly framework for rural children's participation in agricultural production.

The following research hypotheses are also tested in this study:

$\mathrm{H}_{\mathrm{o} 1}$ : There is no significant difference between farm participation levels of schooling and schooling respondents.

$\mathrm{H}_{02}$ : There is no significant difference between the agricultural innovations awareness of schooling and non-schooling respondents. 


\section{Literature Review}

\section{The nature of rural children's participation in family farms activities}

Although children continue to be involved, one way or another, in family farm activities the world over, participation levels and rates differ from one country to another. However, the preponderance of child involvement in farming is felt in Africa and Asia where, according to Lipton (2005), family farms are crucial to poverty reduction. Whether it is the raising of animals or crops, children participate in all production, processing and distribution phases (Idu et al., 2001; Obinne et al., 2002). Even though children mostly carry out 'light' farm tasks such as planting, thinning, picking and transplanting, it is not uncommon that they do get involved in heavy tasks such as land clearing, ridge making, weeding and harvesting (Oworu 1998). Factors such as the absence of family heads and able-bodied male adults as well as an ageing parent population may contribute to these added responsibilities of children on family farms (Jibowo 1992; Abumere et al., 2002; Stloukal 2004). Indeed, Fadayomi (1988) observed that rural children participate in all phases of farm production, irrespective of scale and scope of farm operation. Studies by Adisa (2005) and Agunbiade and Adedoyin (1998) have also shown that many rural children cultivate personal plots on which they often carry out all farm tasks on their own.

\section{Rural farm children and agricultural innovation adoption}

A great challenge facing rural farming in sub-Saharan Africa is yield optimisation. Output per hectare in major staples are still frustratingly low (Ogunwale 1997; Abumere et al., 2002). The use of innovative techniques has thus been seen as a panacea to this undesirable situation. Extension agencies in third world countries have been availing farmers with new, improved technologies with varying degrees of success (Scarborough et al., 1997). Most of these agencies have however paid little or no attention to the peculiar needs of farm children, who constitute a sizeable proportion of the rural farming population (Olawoye 2000). If children, as future farmers, must participate in farming, they need to be safely encouraged to use new methods and tools that are commensurate with their status (Adisa 2005).

\section{Implications of rural children's participation in farming}

Socialisation is the commonest reason advanced as being responsible for rural children's participation in farming (Farinde 1999; Ajayi and Jibowo 2004). It is however clear that in spite of its wide prevalence and other benefits, children's participation in farming brings along with it some grave consequences. Chief among these consequences is its interference with farm 
children's enrolment in school. This interference, according to Mfum-Mensah (2003), cannot be overlooked in planning rural schools' schedules. This is more so considering the fact that about 50 per cent of school age children in Africa fail to complete primary school (Bruns, Mangar and Rakotomalala 2003). The long term socioeconomic implications on school attendance among children cannot be quantified.

Another dangerous twist in children's participation in farming is the vulnerability of the children to health hazards. Even in the United States, Webster and Mariger (1999) wrote that underage children constituted 20 per cent of farm fatalities and that farm children are twice as likely to die in an accident than urban children. While the greatest risks to children in agriculture in developed countries such as the US are tractors, farm machinery and livestock, according to Webster and Mariger (1999), cuts from sharp objects, insect bites, eye irritation from dust and snake bites are the prevalent hazards suffered by farm children in rural Africa (Ajayi and Jibowo 2004).

\section{Framework for rural children's participation in agricultural production}

The need to achieve a balance between the twin desire for compulsory basic education and participation in family farms regarding rural children without, also, compromising their safety and health necessitates this framework. Rural family farm size/output and family socioeconomic status are mutually interrelated. The rural farm output marketing and processing systems are also mutually interdependent and jointly influenced family farm output, as well as by the family adult population.

An ageing farmer population not only has the potential to influence output, but could also determine the role to be taken up by children during farm activities. Government policies and programmes as well as children's NGO intervention should be directed to the encouragement of free basic education and guiding the child's role and interest in farming. A working relationship between Agricultural Extension and rural schools is essential because education is crucial to the effective operation of all rural improvement services. Agricultural Extension could in turn help school farms and Young Farmers' Clubs, and enhance farm health and safety for children. Participation in farming for sustainable rural development would thus be achieved when all stakeholders coordinate and intensify efforts at keeping all rural children in school and ensure their health and safety while working and learning in farms.

\section{Methodology}

The study was conducted in Edu Local Government Area (LGA), which was randomly selected from 16 Local Government Areas of Kwara State, 
Nigeria. It is situated between longitude 4054" and 5036" and latitude $8^{0} 36^{\prime \prime}$ and 9014 " with an area of $1168 \mathrm{~km}^{2}$. As a predominantly farming population, its vegetation is the savannah type, and rainfall lasts from April to October. Nupe is the indigenous language.

The multi-stage cluster random sampling was used to collect data from ten randomly selected villages from each of the three districts (Lafiagi, Tsaragi and Tsonga) that made up the LGA, after a reconnaissance survey. The interview schedule was administered to 247 respondents (aged between 5 and 16 years) with the help of a trained interpreter where (as in most cases) respondents did not understand the English language. Eighteen interview schedules were considered not fit for data analysis, leaving 229. The testretest method was used to determine the reliability of the interview schedule where the correlation coefficient, ( $r$ ) was found to be .84 . Coefficient of farm participation, $c f p$ (in percentage terms) was computed for each respondent as a function of:

(a) days spent in farm per week (maximum points, 10 per cent); (b) hours used on farm per day (maximum 10 per cent); (c) involvement in farm activities namely, land clearing, ridging, planting/transplanting, weeding, input application, pest control, harvesting and produce processing, each of which carry 5 per cent; (d) Participation in school farms (Yes 10 per cent, No 0 per cent); (e) possession of personal plots (Yes 10 per cent, No 0 per cent); (f) raising of farm animals (Yes 10 per cent, No 0 per cent); (g) membership of informal agricultural group(s) (Yes 10 per cent, No 0 per cent). In computing the Innovation Awareness Index (awi), respondents were asked to indicate which of the eight items of agricultural innovations they were aware of. The innovations were: tractor/coupled implements, fertilizer, seed dressing, new crop varieties, credit and loan facilities, chemicals/spraying equipment and livestock vaccination. Each carried a weighting of 12.5 per cent to arrive at a maximum of 100 per cent.

The least square linear multiple regression $\left(Y=f\left(X_{1, \ldots} X n\right)\right)$ was employed in analysing data for determining factors influencing respondents' participation in farming activities. Student's t-test was used to compare farm participation levels of schooling and non-schooling respondents as well as their levels of agricultural innovation awareness. All analyses were at .05 a priori level of significance.

\section{Results and discussion}

Initial analysis of data collected revealed that the sample consisted of 55 per cent boys and 45 per cent girls, and the mean age of respondents was 10.2 years. About 38 per cent were not enrolled in school, while 30 per cent and 22 per cent were respectively in primary and secondary schools. The pre- 
ponderance of farming occupations in the study area was confirmed by the fact that 70 per cent of the respondents were farmers' children.

\section{Factors influencing children's participation in farming}

The results of the multiple regression analysis as presented in Table 1 indicate that the expectation of financial or material gains, parental factor, peer group influence and school farms were significantly related to respondents' involvement in agricultural activities. The value of the Durbin-Watson statistic (2.183) suggests the absence of serial correlation. That school farm was a significant factor is noteworthy as it indicates that the schools in the area were agriculturally active and might have been the source of farm participation for respondents whose parents owned no farms. Because children are prone to form groups and do things the same way, peer group influence was observed to influence respondents' involvement in farming. This coincides with the findings of Pur (1997).

Table 1: Factors influencing children's participation in farming in Edu LGA, Kwara State, Nigeria.

\begin{tabular}{lccccc}
\hline Variable & \multicolumn{1}{c}{$\mathrm{R}$} & $\mathrm{R}^{2}$ & Change in $\mathrm{R}^{2}$ & Adjusted $\mathrm{R}^{2}$ & $\mathrm{t}$ \\
\hline Age & 0.0435 & 0.0019 & - & 0.00186 & 0.432 \\
Financial & 0.0871 & 0.0076 & 0.0057 & 0.00749 & $2.003^{*}$ \\
School farm & 0.0943 & 0.0089 & 0.0013 & 0.00882 & $2.016^{*}$ \\
Parental Influence & 0.0989 & 0.0098 & 0.0009 & 0.00989 & $2.882^{*}$ \\
Amusement & 0.1456 & 0.0212 & 0.0114 & 0.02119 & 1.327 \\
Educational level & 0.1575 & 0.0248 & 0.0036 & 0.0246 & 0.651 \\
Learning & 0.180 & 0.0323 & 0.0075 & 0.00322 & 0.435 \\
Personal interest & 0.1857 & 0.0345 & 0.0022 & 0.0344 & 0.891 \\
Peer group influence & 0.2005 & 0.0402 & 0.0057 & 0.04018 & $2.221^{*}$ \\
Constant & & & 0.0991 & & \\
\hline
\end{tabular}

Durbin-Watson Statistic $=2.138 . \mathrm{N}=229 .{ }^{*}$ - Significant at 0.05 level of probability.

The indication of parental factors as being influential confirms that respondents whose parents owned farms persuaded their wards to work on such farms. Age, learning, personal interest and level of education were not significantly associated with respondents' participation in farming. This could 
be due to the fact that, irrespective of their age or education levels, respondents saw their involvement as a necessity.

\section{Role duality}

An investigation of role duality revealed that about 44 per cent of respondents were simultaneously involved in farming and schooling; 18.8 per cent were schooling but not farming while 33.2 per cent were farming but not schooling (Table 2). It is discernible from Table 2 that 23.1 per cent of respondents spent at least five days (during peak periods) on the farm per week. This implies that such respondents would have missed at least three days of schooling unless those days coincided with holidays, thereby leading to a high rate of failure among rural/farm children. This finding agrees with Knodel and Havanon (1992) that a kind of reciprocal relationship exists between school attendance and farming among children and pre-adolescents.

Table 2: Educational status and days spent on farm per week by children in Edu LGA, Kwara State, Nigeria

\begin{tabular}{|c|c|c|c|c|}
\hline \multirow{2}{*}{$\begin{array}{l}\operatorname{Day}(\mathrm{s}) \\
\text { spent on farm } \\
\text { per week }\end{array}$} & \multicolumn{4}{|c|}{ Educational status } \\
\hline & $\begin{array}{l}\text { Absolute } \\
\text { frequency }\end{array}$ & $\begin{array}{l}\text { Relative } \\
\text { frequency (\%) }\end{array}$ & $\begin{array}{l}\text { Absolute } \\
\text { frequency }\end{array}$ & $\begin{array}{l}\text { Relative } \\
\text { frequency (\%) }\end{array}$ \\
\hline 0 & 43 & 18.8 & 10 & 4.4 \\
\hline $1-2$ & 20 & 8.7 & 12 & 5.2 \\
\hline $3-4$ & 27 & 11.8 & 10 & 4.4 \\
\hline $5-6$ & 45 & 19.6 & 40 & 17.5 \\
\hline 7 & 8 & 3.5 & 14 & 6.1 \\
\hline Total & 143 & 62.4 & 86 & 37.6 \\
\hline
\end{tabular}

A decline in academic performance is obviously possible due to this absenteeism, but it could also be true that this category of respondents might have achieved a goal by keeping away from school to attend to farm work. This is because many respondents claimed to use their financial gains from farming to purchase school items such as textbooks, uniforms, etc. This, ironically, buttresses the view that involvement of children in farming may not entirely lead to the abuse of the child. As found here, involvement in agriculture could be a source of finance for indigent students. It is also not unconnected with the fact that financial gain was a major factor why many re- 
spondents participated in farming. This may buttress the need for a totally free and compulsory basic education.

\section{Farm participation and agricultural innovation awareness}

A $t$-test for significant difference between farm participation levels (cfp) of schooling and non-schooling respondents revealed that at að $=.05$, the critical value 1.96 is greater than the calculated t-value 0.67 implying that there is no significant difference between the means for the two groups (Table 3), indicating that $\mathrm{H}_{\mathrm{o}}$ should be accepted. This may be due to the fact that many respondents missed school days to do farm work. It perhaps also indicated that it made no difference for farm participation for parents to deny their wards outright enrolment in school simply because of farming, because, as it were, those who were in school participated as much as those who were not.

Table 3: Result of $t$-test of means of coefficient of farm participation (cfp) of schooling and non-schooling children in Edu LGA, Kwara State, Nigeria

\begin{tabular}{lcccccc}
\hline Group & $\mathrm{N}$ & $\begin{array}{c}\text { Mean cfp } \\
(\%)\end{array}$ & $\begin{array}{c}\text { Degree } \\
\text { of freedom }\end{array}$ & Variance & $\begin{array}{c}\text { Calculated } \\
t \text {-value }\end{array}$ & $\begin{array}{c}\text { Critical } \\
t \text {-value }\end{array}$ \\
\hline Schooling & 100 & 54.39 & 174 & 795.466 & 0.67 & 1.96 \\
Non-schooling & 76 & 57.27 & - & 792.423 & & \\
\hline
\end{tabular}

Sample mean $\mathrm{cfp}=56.19 \%, \mathrm{~N}=176$.

Farm participation among respondents was just slightly above average as can be seen in Table 3, probably because most respondents were restricted to mainly child-specific operations such as planting, weeding and harvesting. A significant difference was however revealed to exist in their mean agricultural innovation awareness indices (as shown in Table 4) in favour of schooling respondents, thus leading to a rejection of $\mathrm{H}_{\mathrm{o} 2}$. This implies that non-schooling respondent knew less of farm innovations than their colleagues who were school pupils. This agrees with the findings of Pur (1997). It may not necessarily be because they could neither read nor write but probably due to the fact that those in school had the benefit of studying Agricultural Science as a subject in school, and their participation in Young Farmers' 
Table 4: Results of $t$-test between mean agricultural innovation awareness indices of schooling and non-schooling child-farmers in Edu LGA, Kwara State, Nigeria

\begin{tabular}{llllll}
\hline Group & $\mathrm{N}$ & Mean & Variance & Calculated & Critical \\
\hline Schooling & 100 & 57.15 & 522.123 & 6.13 & 1.96 \\
Non-schooling & 76 & 36.92 & 431.808 & & \\
\hline
\end{tabular}

Sample mean awi $=49.6 \%, \mathrm{~N}=176$.

Club, although some non-schooling respondents also belonged to informal farming groups. Thus, schooling respondents could help the innovation adoption process by being information sources for their parents and guardians.

Because awareness is the first stage in the adoption process, this superior awareness level on the part of schooling child farmers could make them better or earlier adopters than their non-schooling counterparts. However, it is observable that total mean awareness index (57.15 per cent) for schooling respondents was below a priori expectation. This may be due to poor information dissemination system, respondents' age (72 per cent of them were below 13 years) and other societal factors. Table 5 shows the awareness rates of the selected innovations. The use of fertilizer was the most widely known among respondents as 88.6 per cent were aware of its existence and function but not necessarily its methods of application and types. It was followed by tractors (85.6 per cent) and seed dressing (73.8 per cent). Respondents might have learnt about these three items from school and within their communities as the LGA had a tractor hiring scheme while fertilizers and dressed seeds were widely used and even sold in small quantities on market days.

Less than 50 per cent of the respondents were aware of each of the other selected innovations. The selection of credit and loan was informed by the presence of a branch of Nigeria Agricultural Cooperative and Rural Development Bank in Lafiagi, the LGA headquarters. The low level of awareness of credit and loans may be due to inadequate publicity and the fact that children were not the particular targets of the bank. Respondents least knew about livestock vaccination probably because respondents were mostly involved in crop rather than animal production. 
Table 5: Awareness rates of selected agricultural innovations among children in Edu LGA, Kwara State, Nigeria

\begin{tabular}{lcc}
\hline $\begin{array}{l}\text { Agricultural } \\
\text { Innovation }\end{array}$ & $\begin{array}{r}\text { Awareness Rate } \\
\text { Absolute frequency }\end{array}$ & Relative frequency (\%) \\
\hline Tractor/coupled implements & 196 & 85.6 \\
Seed dressing & 169 & 73.8 \\
Fertilizer & 203 & 88.6 \\
New crop varieties & 93 & 40.6 \\
Channel Irrigation & 71 & 31.0 \\
Credit \& loan facilities & 8 & 34.1 \\
Chemicals/spraying equipment & 102 & 44.5 \\
Livestock vaccination & 39 & 17.0 \\
\hline
\end{tabular}

$* \mathrm{~N}=229$

\section{Conclusion and policy implications of findings}

The parental factor is still very significant for rural children's participation in agricultural production activities. Indeed, rural children missed school days just to do farm-work despite the observation in this study that there is no significant difference in farm participation levels of schooling and non-schooling respondents. The school can also be used not only to capture children's interest in farming, but was also found in this research to enhance agricultural knowledge among children. This is important since one can only practice or adopt what he/she knows. And with knowledge being the first step in adoption, schooling children are better placed to become good farmers in the future.

The following recommendations are therefore proffered as policy implications of the findings from this research.

- Greater commitment by all stakeholders should be made to get all school-age children enrolled and kept in school.

- The school calendar, especially in rural agrarian areas, may be adapted to suit the farming regime. It may be appropriate to make holidays coincide with peak periods of farming activities.

- Extension workers should make adequate consideration for children in their messages.

- Primary and secondary schools should be supported morally and materially to operate farms to be used as media for making pupils to be interested in farming. 


\section{References}

Abumere, S. I., Okafor, S. I. and Oluwasola, O., 2002, 'Rural Infrastructure and the Development Process in Rural Nigeria’, Research Report No 36, Ibadan: Development Policy Centre.

Adisa, R. S., 2005, 'Use of Agricultural Innovations in Children’s Separate Farm plots in some Villages in Kwara State, Nigeria’, Journal of Extension Systems, Vol. 21, No. 1, pp. 46-57.

Agunbiade, J. B. and Adedoyin, S.F., 1998, 'Socioeconomic Perspectives of the Farmers' Children Farm Plots in the Sustenance of Youth Interest in Agriculture', in Adedoyin, S. F and Torimiro, D. O., eds., Rural Children and Future Food Security in Nigeria, Sageto and Co., Ijebu Igbo, pp. 159-169.

Ajayi, A.O. and Jibowo, A.A., 2004, 'Determinants of Rural Children’s Knowledge of Hazards Associated with Farming in Oyo State, Nigeria', Journal of Social Sciences 9 (3), pp. 195-200.

Bequile, A., 1983, Questions and Answers in Child Labour. Child Labour: A Briefing Manual, Geneva: ILO, pp. 16-24.

Blanchard, F., 1983, Child Labour: A Briefing Manual, Geneva: ILO, p. 3.

Bruns, B., A .Mangar and Rakotomalala, R., 2003, 'Achieving Universal Primary Education by 2015: A Chance for Every Child’, Report No 266605, World Bank. Etim, P. S., 1989, Women and Children under Nigerian Law, Lagos: Federal Ministry of Justice, p.108.

Fadayomi, T.O., 1988, Rural Development and Migration in Nigeria, Ibadan: National Institute of Social and Economic Research (NISER), pp. 36-37.

Farinde, A. J., 1999, 'Issues Crucial to Farm Children Development and Sustainable Agriculture in Nigeria’, in S.B. Williams, F.E. Ogbimi and A. J. Farinde, eds., Farm Children and Agricultural Productivity in the 21st Century, Book of Proceedings, Nigeria CIAP Ago Iwoye, Ogun State, pp. 128-133.

Federal Office of Statistics (Nigeria), 1997, Socioeconomic Profile 1996, Lagos. Ginsberg, O., 2000, 'Sustainability from Children's Perspective: A Journey through the Landscape of German Children's City Farms', Paper presented at University of Nottingham International Conference, 13-16 September.

Idu, E.E., Tee, T.N. and Obinne, A.D.E., 2001, 'Assessment of Children's Participation in Crop and Forest Production: A Case Study of Youths in Makurdi', CIAP Nigeria Book of Proceedings. Makurdi, Nigeria, pp.149-157.

Jibowo, A. A., 1992, Essentials of Rural Sociology, Nigeria: Gbemi Sodipo Press. Kissekka, M.N., 1989, A Brief on Population and socio-cultural life in Nigeria, Lagos: Population Education Series, Department of Population Education, p. 56. Knodel, J. and Havanon, N., 1998, 'The Transition to Secondary School: Views of Parents in a Rural District of Central Thailand', Michigan: Population Studies Center, University of Michigan.

Lipton, M., 2005, 'The Family Farm in a Globalizing World: The Role of Crop Science in Alleviating Poverty', Washington: International Food Policy Research Institute, 2020 Policy Brief No. 74. IFPRI. 
Mfum-Mensah, O., 2003, 'Fostering educational participation in pastoral communities through non formal education; the Ghanaian perspective', International Journal of Educational Development, 23 (6).

Ngwu, P.N.C., 1993, 'Characteristics and Learning Needs of School Leavers in the Rural Small Enterprises Informal Sector in Benue State, Nigeria', Nigeria Journal of Rural Extension and Development, Vol. 1, Nos. 2-3, Owerri, pp. 118.

Obinne, A.D.E., Idu, E.E , and T.N. Tee, 2002, 'Assessment of Youth Participation in Livestock Production and Career Prospects in Agriculture in Makurdi Metropolis', CIAP Nigeria Book of Proceedings. Makurdi, Nigeria, pp. 131137.

Ogunwale, A.B., 1997, 'Socioeconomic Factors Associated with the Adoption of Alley Farming Technology by Small scale Farmers in Osun State’, Unpublished Ph.D Thesis, Ile-Ife, Obafemi Awolowo University.

Olawale, R. and Solola, F., 1991, 'Child Labour in Nigeria', The Guardian, June 16, p 15.

Olawoye, J.E., 2000, 'Contemporary Research Interests and Problem Areas in Agricultural Extension and Rural Development', The Ibadan Extension, Monograph series No. 2, Ibadan: University of Ibadan.

Olutayo, A.O., 1994, 'Systemic Source of Working Children in Africa: The Case of Nigeria', Childhood Journal, (Munskguard), pp. 45-52.

Oworu, O.O., 1998, 'Rural Children and the Continuity and Sustenance of Sugar cane Farming in Nigeria', Farmers' Children and the Future Food Security of Nigeria, Sageto and Co. Ijebu Igbo, pp. 443-449.

Scarborough, V., Killough, S., Johnson, D. A. and Farrington, A., 1997, FarmerLed Extension: Concepts and Practices, London: ITP Ltd.

Stloukal, L., 2004, 'Rural Population Ageing in Developing Countries. Issues for Consideration by FAO', Sustainable Development Dept.

Waldie, K., 2004, 'Youth and rural Livelihoods', LEISA, Vol. 2 No. 2, ILEIA, the Netherlands, pp. 6-8.

Webster, J. and Marigar, S.C., 1999, 'Risks for Children in Agriculture’, Agricultural Health and Safety Fact Sheet AHS 07, Utah State University Extension, Logan, Utah, pp1-2. 